\title{
On the realistic contribution of European forests to reach climate objectives
}

\author{
Giacomo Grassi ${ }^{*} \mathbb{C}$, Alessandro Cescatti ${ }^{1}$, Robert Matthews², Gregory Duveiller ${ }^{1}$, Andrea Camia', \\ Sandro Federici ${ }^{3}$, Jo House ${ }^{4}$, Nathalie de Noblet-Ducoudré ${ }^{2}$, Roberto Pilli ${ }^{1}$ and Matteo Vizzarri ${ }^{1}$
}

\begin{abstract}
A recent article by Luyssaert et al. (Nature 562:259-262, 2018) analyses the climate impact of forest management in the European Union, considering both biogeochemical (i.e., greenhouse gases, GHG) and biophysical (e.g., albedo, transpiration, etc.) effects. Based on their findings, i.e. that additional net overall climate benefits from forest management would be modest, the authors conclude that the EU "should not rely on forest management to mitigate climate change". We first explain that most of the additional EU GHG mitigation effort by 2030 is expected to come from emission reductions and only a very small part from forestry, even when forest bioenergy is allowed for. Nevertheless, the inclusion of forest management in climate change mitigation strategies is key to identifying the country-specific optimal mix, in terms of overall GHG balance, between strategies focused on conserving and/or enhancing the sink and strategies focused on using more wood to reduce emissions in other GHG sectors. Then, while acknowledging the importance that biophysical effects have on the climate, especially at the local and seasonal scale, we argue that the net annual biophysical climate impact of forest management in Europe remains more uncertain than the net $\mathrm{CO}_{2}$ impact. This has not been adequately emphasized by Luyssaert et al. (2018), leading to conclusions on the net overall climate impact of forest management that we consider premature and applied to a partially biased perception of European policy towards forestry and climate change. To avoid further confusion in the debate on how forestry may contribute to mitigating climate change, a more constructive dialogue between the scientific community and policy makers is needed.
\end{abstract}

Keywords: EU climate target, Forest mitigation, GHG emissions, Biophysical effects, Bioenergy

\section{Background}

A recent article by Luyssaert et al. [1] analyses the climate impact of forest management in the European Union (EU) considering both biogeochemical (i.e., greenhouse gases, GHG) and biophysical (e.g., albedo, transpiration, etc.) effects. The context of the paper is the EU's climate target under the Paris Agreement, i.e. a 40\% reduction in GHG emissions by 2030 compared to 1990 levels (equivalent to a reduction of about $2250 \mathrm{Mt} \mathrm{CO}_{2} \mathrm{e} /$ year). In the original version of the paper, a key premise was that "about $75 \%$ of this reduction is expected to come from emission reductions and the remaining $25 \%$ from land use, land-use change and forestry", citing Grassi et al.

\footnotetext{
*Correspondence: giacomo.grassi@ec.europa.eu

${ }^{1}$ European Commission, Joint Research Centre, 21027 Ispra, VA, Italy

Full list of author information is available at the end of the article
}

[2]. Based on their findings, i.e. that additional net climate benefits from forest management would be modest, Luyssaert et al. [1] conclude that the EU "should not rely on forest management to mitigate climate change".

The original premise of Luyssaert et al. [1] on the expected large role of forestry in meeting the EU climate targets reflected a misinterpretation of Grassi et al. [2]. In fact, Grassi et al. [2] assume that the portion of the EU GHG mitigation target contributed by the land use, land-use change and forestry (LULUCF) sector is zero, consistent with [3]. The value of $25 \%$ refers to the globally aggregated contribution from LULUCF to the Nationally Determined Contributions made in Paris, mostly associated with the reduction of deforestation expected in the 2030 climate targets of Brazil and Indonesia (see Fig. 1 and Additional file 1: Section S1). This mistake has been

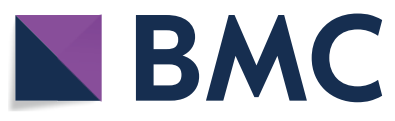

(c) The Author(s) 2019. This article is distributed under the terms of the Creative Commons Attribution 4.0 International License (http://creativecommons.org/licenses/by/4.0/), which permits unrestricted use, distribution, and reproduction in any medium, provided you give appropriate credit to the original author(s) and the source, provide a link to the Creative Commons license, and indicate if changes were made. The Creative Commons Public Domain Dedication waiver (http://creativecommons.org/ publicdomain/zero/1.0/) applies to the data made available in this article, unless otherwise stated. 


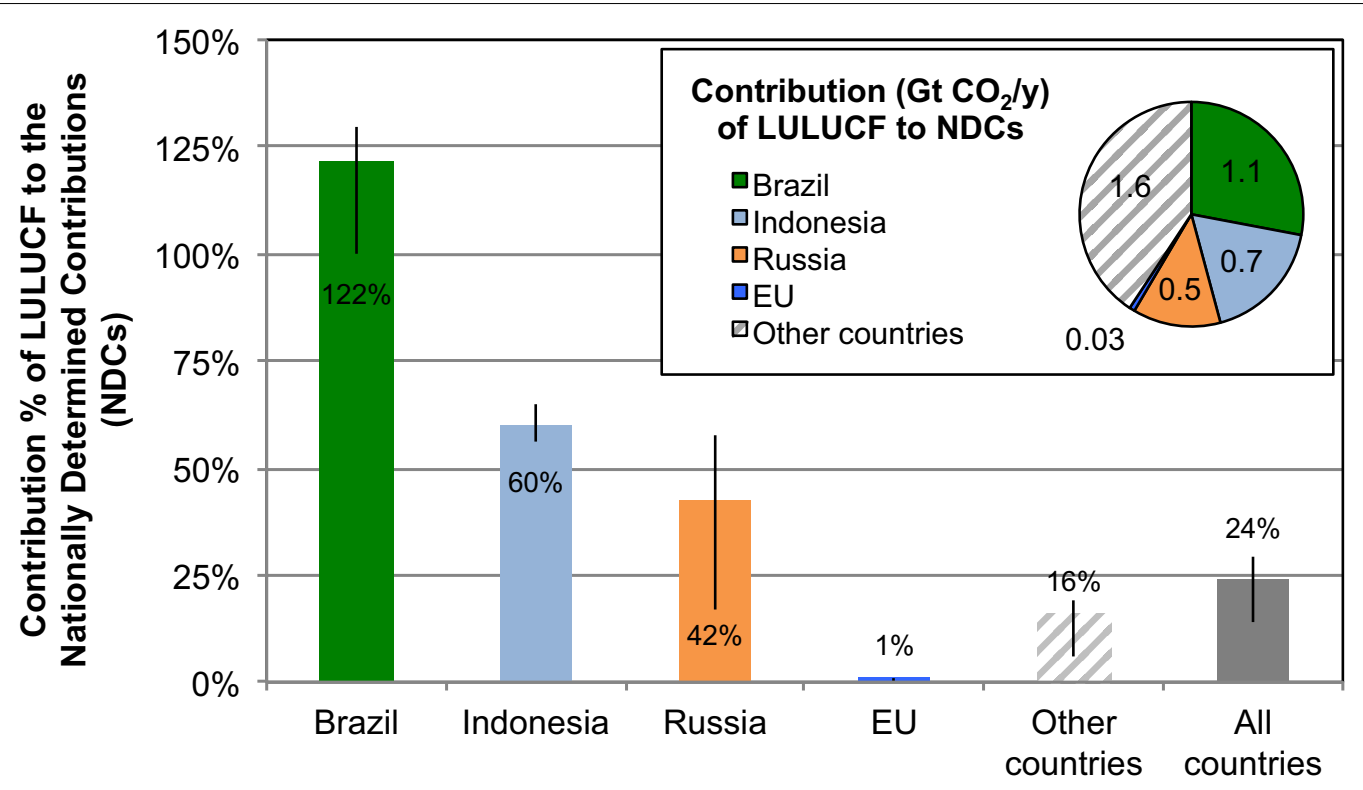

Fig. 1 Contribution of LULUCF to the Nationally Determined Contributions (NDCs) in 2030 of Brazil, Indonesia, Russia and the EU, based on the analysis of Grassi et al. [2] expressed in \% of the total $\mathrm{GHG}$ emissions reduction (main graph) and in $\mathrm{GtCO}_{2} /$ year (small graph). The original estimate by Grassi et al. [2] for the EU (zero) is updated here to consider the recent EU LULUCF legislation [7] that caps the contribution from LULUCF toward the EU target at $280 \mathrm{MtCO}_{2} \mathrm{e}$ for the 10-years period 2021-2030: if this value is annualized (i.e., $28 \mathrm{MtCO}_{2} \mathrm{e} /$ year), it corresponds to slightly more than $1 \%$ of the EU 2030 emission reduction target (which is about $2250 \mathrm{Mt} \mathrm{CO}_{2} \mathrm{e} /$ year, i.e. from about $5650 \mathrm{Mt} \mathrm{CO}_{2} \mathrm{e} /$ year in 1990 to about 3400 $\mathrm{Mt} \mathrm{CO}_{2} \mathrm{e} /$ year in 2030). More information on the NDCs is in Additional file 1: Table S1. For further details, see Fig. 4b, supplementary section 2 and supplementary Table 5 in Grassi et al. [2]

acknowledged by Luyssaert et al. and a subsequent correction was published [4].

In this commentary, we discuss further several of the arguments by Luyssaert et al. [1], showing why a large additional mitigation contribution by European forests towards climate objectives is unrealistic, and offering a different view on the relative importance of biophysical vs. biogeochemical climate effects of forest management in the EU.

\section{Main text}

Considering that the current carbon sink in the EU LULUCF sector is about $300 \mathrm{Mt} \mathrm{CO}_{2} /$ year (about 400 $\mathrm{MtCO}_{2} \mathrm{e}$ year for forests alone)-offsetting about 7\% of total EU GHG emissions, with rather stable values in the last 25 years [5], reaching a $25 \%$ contribution would require (i) that the current LULUCF sink nearly doubles by 2030 , something not supported by any peer-reviewed publication, and (ii) that this sink is entirely counted as a mitigation effort towards the EU 2030 target. This second point has never been seriously considered in the political debate, because it has long been recognized that the existing forest sink is not entirely a result of direct and recent mitigation actions, but instead largely due to historic management activities and the effects of environmental change [6, 7] (see Additional file 1: Section S2.1).
Accordingly, in the recent EU LULUCF legislation [8] not all of the forest management sink will count toward the mitigation target. Instead, only the portion that will exceed a predefined science-based "forest reference level" benchmark will count $[7,9]$, reflecting the atmospheric impact of additional actions. In the event that the forest sink is smaller than this benchmark, then the corresponding accounted "debit" from forest management will need to be compensated for, through extra emission reductions in other land uses or in other GHG sectors, such as energy.

Furthermore, the EU climate legislation [10] has capped both the amount of possible "credits" from managed forest land (equal to $3.5 \%$ of 1990 emissions) and the maximum contribution from the LULUCF sector toward the EU target at $280 \mathrm{MtCO}_{2} \mathrm{e}$ for the period 2021-2030. If this latter value is annualized (i.e., $28 \mathrm{MtCO}_{2} \mathrm{e} /$ year), it corresponds to about $1 \%$ of the EU 2030 emission reduction target. Therefore, contrary to the assumption of Luyssaert et al., almost all of the EU mitigation effort in 2030 is expected to come from emission reductions from non-LULUCF sectors and only a very small part directly from LULUCF.

Forests may contribute to mitigation also indirectly, especially through the utilization of wood as an energy source in place of fossil fuels. When the harvesting 
of forest biomass for energy purposes is increased, a decrease in carbon stock is reported in the LULUCF sector whilst GHG emission savings appear in the energy sector. For the EU, these savings are currently estimated to be about $130 \mathrm{MtCO}_{2} \mathrm{e} /$ year [11], relative to about 90 $\mathrm{MtCO}_{2} \mathrm{e} /$ year in 1990 (see Additional file 1: Section S2.2). Several studies suggest a larger future potential associated with additional sustainable harvest of EU wood for bioenergy [12]. However, since this additional harvest would temporarily lower the forest sink, the relevant question is which portion of this bioenergy potential can be realized without generating accounted debits in the forestry and consequently in the LULUCF sector by 2030 . Based on various sources $[7,11,13]$, and assuming no LULUCF debits, we estimate that EU forest-based bioenergy derived from additional harvest could save about $150 \mathrm{MtCO}_{2} \mathrm{e} /$ year in 2030. Relative to the EU's climate target under the Paris Agreement (reduction of about $2250 \mathrm{Mt} \mathrm{CO}_{2} \mathrm{e}$ /year from 1990 to 2030), the indirect contribution of EU forest-based bioenergy to the EU 2030 emission reduction target would realistically add another $3 \%((150-90) / 2250)$.

We fully share with Luyssaert et al. [1] the view that forest management strategies aiming at climate change mitigation should not focus solely on GHG emissions, but should consider also any robust evidence on the potential impact of biophysical effects. However, we think that the uncertainty of the findings by Luyssaert et al. [1] has not been adequately emphasized. Although the local and seasonal climate biophysical effects can be retrieved with some confidence-e.g. afforestation warms winter surface temperature (decreased albedo) and cools summer surface temperature (increased evapotranspiration) [14] - the net annual impact of combined local and non-local effects in temperate zones, such as most of the EU, is highly uncertain. This is because in temperate regions radiative and non-radiative effects have similar magnitude but opposite impacts on the mean annual temperature. As a result, observation-based assessments and models don't agree on the magnitude, and often not even on the sign, of the net annual biophysical climate effects of forestry in temperate zones [15, 16]. Despite the good advancements in Luyssaert et al's model (e.g., in representing differences between tree species and stand structures), the net annual biophysical climate impact of forest management in the EU remains more uncertain than the net $\mathrm{CO}_{2}$ impact. Rather than emphasizing these crucial caveats, Luyssaert et al. [1] used their results on the combined biophysical and biogeochemical effects to challenge their perception of EU policy towards forestry and climate change.

If the aim is to encourage countries to start considering biophysical effects in their policies, more emphasis should be put on seasonal and local impact of biophysical effects of forest cover change, including synergies and trade-offs with a carbon-oriented management, rather than on the net annual biophysical climate impact at EU level. These seasonal and local impacts are less uncertain and more relevant in the context of changes in diurnal temperature excursions [17] and heat extremes [18], and therefore for our perception of climate change. Concrete and accessible tools should be developed to allow countries to assess themselves the biophysical effects of different forest management scenarios [19]. Furthermore, model projections should be complemented with observational evidences, and a comprehensive communication of the uncertainty and range of applicability of the scientific findings is required to gain credibility in the policy domain.

Irrespective of the high uncertainty of biophysical effects on climate, the argument by Luyssaert et al. [1], that efforts for enhancing the $\mathrm{CO}_{2}$ sink from forest management are counterbalanced by negative biophysical climate effects-resulting in a "zero-sum" climate outcome, could be interpreted as forest management not being important to fight climate change. We think that would be a wrong conclusion. In fact, the recent inclusion of forests into the EU 2030 economy-wide climate targets [8] represents a key incentive for identifying the country-specific optimal mix, in terms of overall GHG balance, between strategies focused on conserving and/ or enhancing the sink, as explicitly requested by the Paris Agreement (Art. 5), and strategies focused on using more wood to reduce emissions in other GHG sectors (including both energy and material substitution [20]). Without political "sticks and carrots" on GHG emissions, i.e. if forests were excluded from climate change mitigation strategies, there would be no incentive for conserving the current forest $\mathrm{CO}_{2}$ sink, and no disincentive for a possible over-use of forest resources (e.g., for bioenergy purposes), which could drastically reduce the current $\mathrm{CO}_{2}$ sink.

\section{Conclusions}

In conclusion we argue that, while biophysical effects are clearly important on the local and seasonal climate, the net annual biophysical climate impact of forest management in Europe remains more uncertain than the net $\mathrm{CO}_{2}$ impact. Therefore, in our view, the conclusion of Luyssaert et al. [1] that the efforts for enhancing the $\mathrm{CO}_{2}$ sink from forest management at EU level are counterbalanced by negative biophysical climate effects is uncertain and premature. Furthermore, we show that the GHG mitigation contribution by forests towards EU 2030 climate objectives is expected to be small, but yet strategically important. Although the original mistake 
by Luyssaert et al. [1] on the expected large contribution of EU forests toward climate targets has been corrected, it reflects a misunderstanding of the policy context. These types of misunderstandings should be avoided, especially in high-visibility journals, because they create confusion in the debate on how forests may contribute to climate targets, such as the newly started discussion on the EU 2050 GHG strategy [21]. They also risk distracting the attention from the key intended message of the paper, hampering the prospect that biophysical effects of forest management-recently subject of a rising interest [22]-are seriously considered by policy makers. We hope that the clarifications provided here will foster a more correct understanding of the realistic role of forests within the EU climate targets and under the Paris Agreement [23], and encourage a more constructive dialogue between the scientific community and policy makers.

\section{Additional file}

Additional file 1. The contribution of LULUCF to the countries' climate pledges made in Paris and, more specifically, the expected contribution of forests to meet EU 2030 the climate targets, including an analysis of forest-based bioenergy.

\section{Abbreviations}

EU: European Union; GHG: greenhouse gases; LULUCF: land use, land-use change and forestry.

\section{Acknowledgements \\ The authors thank G. Hogan and E. Mackie from Forest Research (UK) for help- ing in the calculations of forest-based bioenergy, and L. Marelli con helpful comments. \\ The views expressed are purely those of the writers and may not in any circumstances be regarded as stating an official position of the European Commission or any other Government Agency.}

\section{Authors' contributions}

GG designed the analysis and wrote a first version of the text. $A C$ and $G D$ contributed on biophysical effects. RM and AC contributed on forest-based bioenergy calculations. JH refined the text. All authors contributed to commenting and refining the manuscript. All authors read and approved the final manuscript.

\section{Funding}

All authors were supported by their respective Institutions.

\section{Availability of data and materials}

The data supporting our conclusions on the contribution of forests to the EU climate targets are available either in the paper itself or in the papers listed in the references. Additional data may be requested from the corresponding author.

\section{Ethics approval and consent to participate} Not applicable.

\section{Consent for publication}

Not applicable.

\section{Competing interests}

The authors declare that they have no competing interests.

\section{Author details}

${ }^{1}$ European Commission, Joint Research Centre, 21027 Ispra, VA, Italy. ${ }^{2}$ Forest Research, Alice Holt Lodge, Farnham GU10 4LH, UK. ${ }^{3}$ Climate and Environment Division, FAO, 00153 Rome, Italy. ${ }^{4}$ Department of Geographical Sciences, Cabot Institute, University of Bristol, Bristol BS8 1SS, UK. ${ }^{5}$ Laboratoire des Sciences du Climat et de l'Environnement LSCE/IPSL, Unité mixte CEA-CNRS-UVSQ, Université Paris-Saclay, 91191 Gif-sur-Yvette, France.

Received: 22 February 2019 Accepted: 29 May 2019

Published online: 14 June 2019

\section{References}

1. Luyssaert S, et al. Trade-offs in using European forests to meet climate objectives. Nature. 2018;562:259-62.

2. Grassi $\mathrm{G}$, et al. The key role of forests in meeting climate targets requires science for credible mitigation. Nat Clim Chang. 2017;7:220-6.

3. European Commission (EC). Impact assessment of proposal for a regulation on the inclusion of greenhouse gas emissions and removals from land use, land use change and forestry into the 2030 climate and energy Framework. 2016

4. Luyssaert S, et al. Author correction: trade-offs in using European forests to meet climate objectives. Nature. 2018;567:E13.

5. EEA (European Environment Agency). Annual European Union greenhouse gas inventory 1990-2016 and inventory report 2018. Submission to the UNFCCC Secretariat. 2018.

6. Canadell JG, et al. Factoring out natural and indirect human effects on terrestrial carbon sources and sinks. Environ Sci Policy. 2007;10:370-84.

7. Grassi G, Pilli R, House J, Federici S, Kurz WA. Science-based approach for credible accounting of mitigation in managed forests. Carbon Balance Manag. 2018;13:8.

8. EU (European Union). Regulation (EU) 2018/841 of the European Parliament and of the Council of 30 May 2018 on the inclusion of greenhouse gas emissions and removals from land use, land use change and forestry in the 2030 climate and energy framework, and amending Regulation (EU) No 525/2013 and Decision No 529/2013/EU (Text with EEA relevance). 2018.

9. Forsell N, et al. Guidance on developing and reporting Forest Reference Levels in accordance with regulation (EU) 2018/841. 2018. https://publi cations.europa.eu/en/publication-detail/-/publication/5ef89b70-8fba11e8-8bc1-01aa75ed71a1/language-en. Accessed 3 June 2019.

10. EC (European Commission). 2030 climate \& energy framework. https:// ec.europa.eu/clima/policies/strategies/2030_en. Accessed 3 June 2019.

11. Matthews R, et al. Carbon impacts of biomass consumed in the EU: quantitative assessment. Final report, project: DG ENER/C1/427 Part A: main report. 2015 .

12. Nabuurs GJ, et al. By 2050 the mitigation effects of EU forests could nearly double through climate smart forestry. Forests. 2017;8:484.

13. Nabuurs G-J, Arets EJMM, Schelhaas M-J. Understanding the implications of the EU-LULUCF regulation for the wood supply from EU forests to the EU. Carbon Balance Manag. 2018;13:18.

14. Strandberg G, Kjellström E, Strandberg G, Kjellström E. Climate impacts from afforestation and deforestation in Europe. Earth Interact. 2018. https ://doi.org/10.1175/El-D-17-0033.1.

15. Perugini $\mathrm{L}$, et al. Biophysical effects on temperature and precipitation due to land cover change. Environ Res Lett. 2017;12:053002.

16. Duveiller $\mathrm{G}$, et al. Biophysics and vegetation cover change: a processbased evaluation framework for confronting land surface models with satellite observations. Earth Syst Sci Data. 2018;10:1265-79.

17. Alkama R, Cescatti A. Biophysical climate impacts of recent changes in global forest cover. Science. 2016;351(6273):600-4. https://doi. org/10.1126/science.aac8083.

18. Lejeune Q, Davin EL, Gudmundsson L, Seneviratne SI. Historical deforestation increased the risk of heat extremes in northern mid-latitudes 2. Nat Clim Chang. 2018;8(5):1-16. https://doi.org/10.1038/s41558-018-0131-z.

19. Duveiller G, Hooker J, Cescatti A. A dataset mapping the potential biophysical effects of vegetation cover change. Sci Data. 2018;5:180014. 
20. Kurz W, Smyth C, Lemprière T. Climate change mitigation through forest sector activities: principles, potential and priorities 1. Unasylva. 2016;67:61-7

21. EC (European Commission). A clean planet for all. A European strategic long-term vision for a prosperous, modern, competitive and climate neutral economy. https://eur-lex.europa.eu/legal-content/EN/ TXT/?uri=CELEX:52018DC0773. Accessed 3 June 2019.

22. Popkin G. The forest question. Nature. 2019;565:280-2.
23. Grassi $G$, et al. Reconciling global-model estimates and country reporting of anthropogenic forest $\mathrm{CO}_{2}$ sinks. Nat Clim Chang. 2018;8:914-20.

\section{Publisher's Note}

Springer Nature remains neutral with regard to jurisdictional claims in published maps and institutional affiliations.
Ready to submit your research? Choose BMC and benefit from:

- fast, convenient online submission

- thorough peer review by experienced researchers in your field

- rapid publication on acceptance

- support for research data, including large and complex data types

- gold Open Access which fosters wider collaboration and increased citations

- maximum visibility for your research: over $100 \mathrm{M}$ website views per year

At BMC, research is always in progress.

Learn more biomedcentral.com/submissions 